\title{
Estimating Numbers of Rodents and Edge Effect Using a Modified Version of the Standard Minimum Method
}

\author{
Stanisław CHUDOBA \& Stanisław HUMIÑSKI
}

Chudoba S. \& Humiński S., 1980: Estimating numbers of rodents and edge effect using a modified version of the standard minimum method. Acta theriol., 25, 29: 365-376 [With 5 Tables \& 5 Figs.]

Studies on numbers of small rodents were carried out from 19671968 in the Slęża woodlands (Lower Silesia) situated at a height of $400-500 \mathrm{~m}$ above sea level. Three cycle of removals of these animals were made, using for the second and third cycles a modified "Standard Minimum « area. Modification consisted in enlarging the trapping area and forming on its edge a barrier of densely arranged traps. This barrier made it easier to trace the formation of what is known as the edge effect and to interpret it. The authors consider that baiting leads to differentiation of the study area from its surroundings favourable to rodents and consequently leads to distortion of results.

[Agric. Acad., Dept. Zool., Cybulskiego 20, 50-205 Wrocław]

\section{INTRODUCTION}

Numbers of rodents and the edge effect in different ecosystems are estimated on the basis of the results of systematic removals. The "Standard Minimum " method was used in studies carried out under the International Biological Programme (Grodziński, P uce k \& R y s zkowski, 1966; Aulak, 1967; Chełkowska \& Ryszkowski, 1967; P elikán, 1968, 1968; H a n s o n, 1969).

The purpose of the studies was to obtain information on the density of small rodents in a mountainous area and to attempt to make a practical estimate and eliminate error arising from the edge effect.

\section{AREA, METHODS AND MATERIAL 。}

The study area was situated in the Slęża woodlands situated at a height of $400-500 \mathrm{~m}$ above sea level with an average inclination of about $15^{\circ}$. No exact description of the Sudeten woodland flora has so far been made ( $\mathrm{S} \mathrm{z}$ a f e r, 1972). The prfedominating three stands of the Slęża massif belong to the QuercoCarpinetum fagetosum association. In the study area itself the basic plant component was spruce, with an admixture of pine, fir, oak, beech and servicetree. The undergrowth is sparse and consists mainly of young beech trees and Sambucus racemosa. The herb layer is varied, consisting of Majanthemum bifolium, Hieracium murorum, Fragaria vesca, Vaccinium myrtillus, Viola silvestris, and grassy patches with Carex or Luzula, or mosses (Leucobryum glaucum). 
The woodland area chosen gave good access to light and was not very humid, particularly in the higher part. The degree of humidity can be partly determined by the average temperatures and precipitation in the Slęża area, measured in years and months of the studies.

\author{
Temperature, ${ }^{\circ} \mathrm{C}$ \\ Precipitation, $\mathrm{mm}$ \\ Mean yearly precipitation, $\mathrm{mm}$
}

Total yearly precipitation, $\mathrm{mm}$

\begin{tabular}{|c|c|c|}
\hline Oct. 1967 & June 1968 & Oct. 1968 \\
\hline 9.9 & 14.5 & 7.2 \\
\hline 61 & 146 & 48 \\
\hline 75 & & \\
\hline 904 & & \\
\hline
\end{tabular}

Three cycles of removals of small mammals were carried out in the following periods: autumn (October) 1967, spring (June) 1968 and autumn (October) 1968. The first cycle of removals took place without using bait in a "Standard Minimum " (SM) area measuring 5.76 ha, with trapping stations provided with two snap traps per station set out in a grid $15 \times 15 \mathrm{~m}$. The two remaining removal cycles took place in a modified area. Modification consisted in forming an additional external zone of traps, thus increasing the extent of the study area to 7.39 ha and the number of trapping stations with simultaneous formation of the edges of the trapping area of so-called barrier. This barrier was formed by: 1 . three additional lines of traps - two on outer and one on the inner side of the extreme edge of the SM area, the distance between these trap lines being $7.5 \mathrm{~m}$; 2. Double density of traps in the three extreme lines, with the exception of the outermost one. The five outer lines therefore had a different grid of traps than that of the core zone of the study area (inner lines). The first line, i.e., the edge line, and the five outer lines constituted the approach to the actual barrier (Fig. 1).

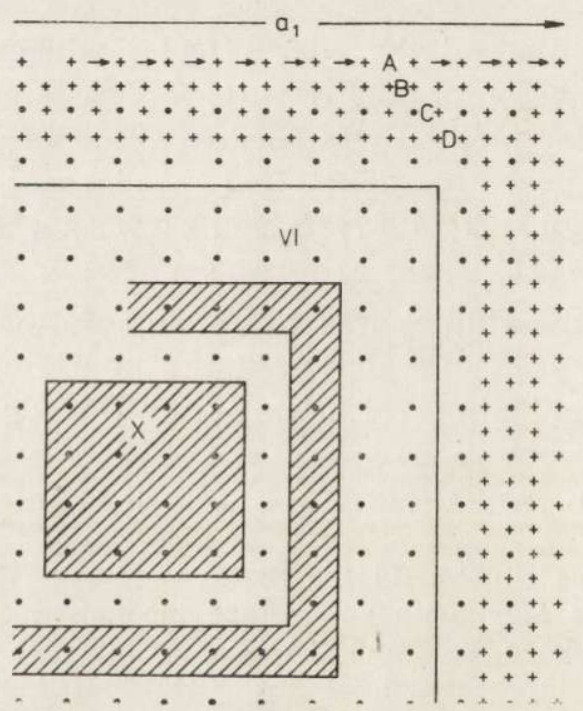

Fig. 1. Plan of modified trapping area (see text for details).

Only one trap was in operation on each trapping station of the modified area. The purpose of the barrier was to eliminate, or at least limit, the passage of small mammals to and from the control area.

The concentric lines of traps were indicated by capital letters of the alphabet, and the sides of the different squares by small lettẹs $\left(a_{1}, a_{2}, a_{3}, b_{1}, b_{2}\right.$ etc.), 
The areas of gradually diministing squares were indicated by Roman numerals I to XI (the boundary of square $\mathrm{V}$ is shown on Fig. 1 and the whole area of square $\mathrm{X}$ has been shaded), and Arabian numerals - the area of belts, i.e., areas adjacent on both sides of a given line (the area of belt 8 has been shaded).

Part of largest trapping belt indicated by letter A, and its side by the letter $a_{1}$. Square $X$ and part of the area of belt 8 is shaded and the boundaries of square VI are indicated by continuous line. Five external belts of traps form a distinct barrier. Within this barrier dots indicate standard trapping stations, and crosses - additional trapping stations.

\section{RESULTS}

\section{Material}

A total of 560 small rodents (Tables 1,2 ) belonging to 6 species, was obtained from all trapping series. In addition 59 individuals of Sorex araneus Linnaeus, 1758 and 18 Sorex minutus Linneaus, 1766 were

Table 1

List of species and numbers of individuals removed in different trapping cycles.

\begin{tabular}{|c|c|c|c|c|}
\hline Species & $\begin{array}{c}\text { Autumn } \\
\text { (Oct., } \\
1967)\end{array}$ & $\begin{array}{c}\text { Spring } \\
\text { (June, } \\
1968 \text { ) }\end{array}$ & $\begin{array}{c}\text { Autumn } \\
\text { (Oct., } \\
1968 \text { ) }\end{array}$ & Total \\
\hline Apodemus tauricus (Pallas, 1811) & 62 & 10 & 18 & 90 \\
\hline Apodemus agrarius (Pallas, 1771) & - & - & 57 & 57 \\
\hline Micromys minutus (Pallas, 1778) & - & & 6 & 6 \\
\hline Clethrionomys glareolus (Schreber, 1780) & 62 & 33 & 250 & 345 \\
\hline $\begin{array}{l}\text { Microtus arvalis (Pallas, 1779) } \\
\text { Pitymys subterraneus (de Sélys- }\end{array}$ & - & - & 60 & 60 \\
\hline $\begin{array}{l}\text { Pitymys subterraneus (de Sélys- } \\
\text { Longchamps, 1835) }\end{array}$ & - & - & 2 & 2 \\
\hline Total & 124 & 43 & 393 & 560 \\
\hline
\end{tabular}

Table 2

Number of all rodents in autumn 1968 on the modified area.

\begin{tabular}{rccccc} 
& Square & & & Number & of individuals caught \\
\cline { 5 - 6 } \cline { 4 - 5 } No. & Side, $\mathrm{m}$ & Area, ha & $\mathrm{N}$ & N/ha \\
\hline I & 270.0 & 7.39 & 393 & 53.2 \\
II & 247.5 & 6.13 & 340 & 55.5 \\
III & 232.5 & 5.40 & 269 & 49.7 \\
IV & 217.5 & 4.73 & 186 & 39.3 \\
V & 202.5 & 4.10 & 125 & 30.5 \\
VI & 180.0 & 3.24 & 100 & 30.9 \\
VII & 150.0 & 2.25 & 67 & 30.0 \\
VIII & 120.0 & 1.44 & 33 & 23.0 \\
IX & 90.0 & 0.81 & 17 & 21.0 \\
X & 60.0 & 0.36 & 10 & 28.0 \\
XI & 30.0 & 0.09 & 2 & 22.2 \\
\hline
\end{tabular}

caught. The considerable differences in the number of species and individuals caught in two successive autumn seasons can be clearly seen from Table 1. This applies particularly to Apodemus tauricus 
(Pallas, 1811) which, in addition to Clethrionomys glareolus (Schreber, 1780), is the main component of the rodent fauna of the forest ecosystems studied.

\section{Rate of Removing Rodents}

On the first day of each trapping cycle the percentage of rodents caught was from 23.2 to $40.3 \%$. On subsequent days the removal rate of animals was far more balanced (Fig. 2). After five days from 82.2

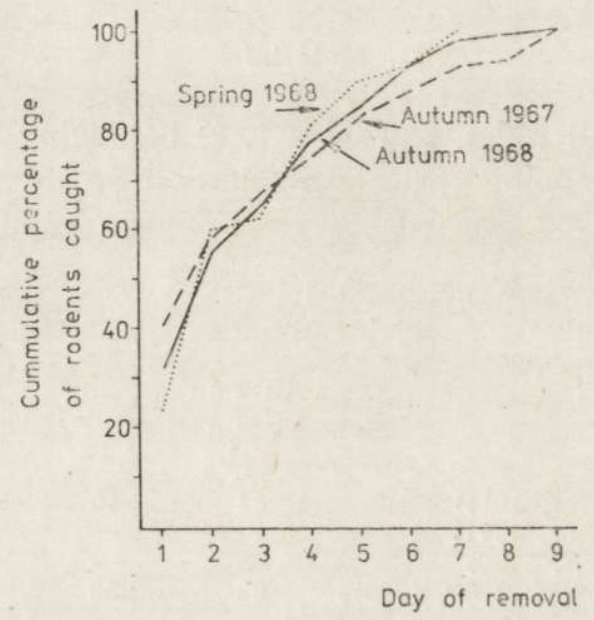

Fig. 2. Rate of removal of rodents in different seasons and years.

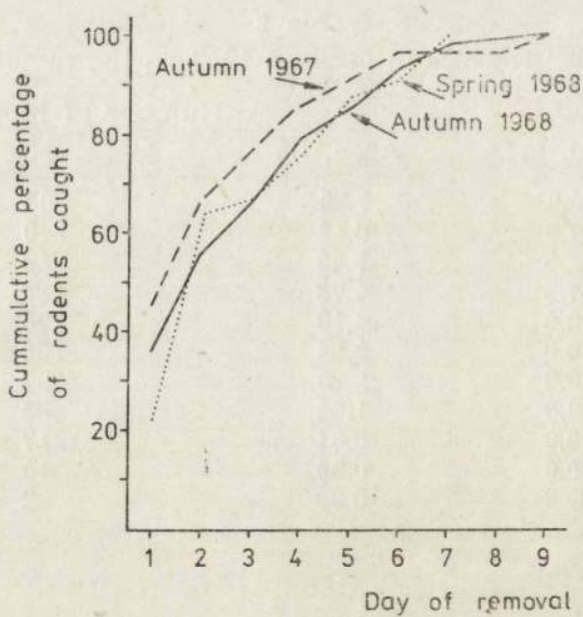

Fig. 3. Rate of removal of Clethrionomys glareolus in different seasons and years. 
to $90.6 \%$ of rodents were removed from the experimental areas. Fig. 3 shows the removal curves for Clethrionomys glareolus and forms evidence that there are only slight differences between seasons in the removal rate of rodents. This question has not been analyzed in the case of other species on account of the relatively small amount of material obtained.

Table 3

Intensity of removal of rodents presented in cumulative percentages.

\begin{tabular}{|c|c|c|c|c|c|c|c|c|c|c|}
\hline \multirow[t]{2}{*}{ Species } & \multicolumn{9}{|c|}{ Successive days of removal } & \multirow{2}{*}{$\begin{array}{c}\text { Total no. of } \\
\text { individuals } \\
\text { removed }\end{array}$} \\
\hline & 1 & 2 & 3 & 4 & 5 & 6 & 7 & 8 & 9 & \\
\hline 19 & & & & & & & & & & \\
\hline All & 40.3 & 58.8 & 66.8 & 74.1 & 83.1. & 87.9 & 92.7 & 93.5 & 100.0 & 124 \\
\hline A. taur & 35. & 50 & 56. & 63. & 69.6 & 82.5 & 85 & & & 62 \\
\hline $\begin{array}{l}\text { C. glareolus } \\
1968\end{array}$ & 45. & 67.7 & 77.4 & 85.5 & 90.4 & 96.9 & 96.9 & 96.9 & 100.0 & 62 \\
\hline All rodents & 32.0 & 55.5 & 68.0 & 76.9 & 84.0 & 92.1 & 98.0 & 99.0 & 100.0 & 393 \\
\hline A. $a g r$ & 33. & 61.4 & 71.9 & 75.4 & 82.4 & & 96 & 96.4 & & 57 \\
\hline C. glareolus & 35.2 & 55.6 & 6922 & 79.2 & 86.0 & 93.2 & 98.8 & 99.6 & 100.0 & 250 \\
\hline
\end{tabular}

Removal rate for all rodents, including species not exhibiting removal regression, are shown in Table 3 . The two dominating species, Apodemus tauricus and Clethrionomys glareolus, are shown separately.

\section{Estimating Numbers of Rodents}

The number of rodents caught in the "Standard Minimum" area (5.76 ha) in the autumn of 1967 during a 9-day period was 124 individuals (Table 1). Theoretical estimates obtained from the linear regression equation calculated for the first three days of removal are far lower 91 individuals. Density of settlement by rodents is respectively 21.5 and 16.8 individuals/ha (Table 4).

Fig. 4 illustrates the density of rodents in different belts of the study area. Maximum density is found in the two external belts $(1,2)$. This result is undoubtedly due to the edge effect; this phenomenon having been manifested as from the first day of the studies. The remaining belts exhibited lesser and far more balanced density.

Removals carried out in June 1968 on the modified area (7.39 ha) were very small (Table 1). Analysis of results showed that the area was settled by small rodents in wislands ", with extremely distinct isolation of A. tauricus and C. glareolus.

A total of 393 small rodents (i.e., 53 individuals per hectare) were caught in the autumn of 1968 in the modified area (Tables 1,2). Results 
obtained from calculation of linear regression for all species of rodents removed during the first three days are very similar to empirical data, with 376 rodents, which corresponds to 50.9 individuals per hectare (Table 4). In this removal series species were caught which did not exhibit removal regression i.e. Microtus arvalis, Micromys minutus. In

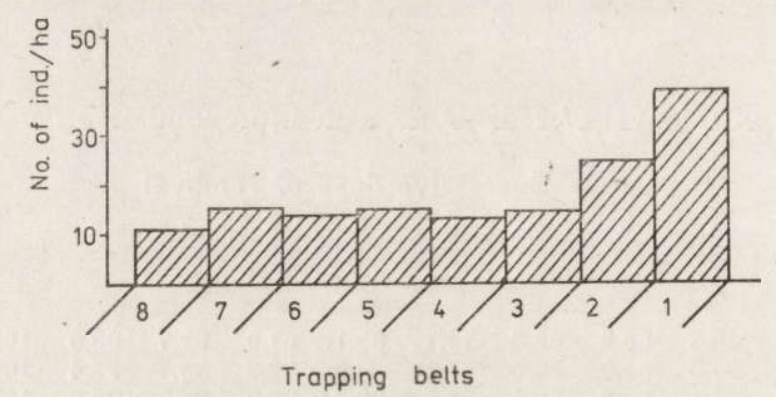

Fig. 4. Density of small rodents on the standard area in autumn 1967 converted to area of 1 ha.

\section{Table 4}

Empirical and theortical number of rodents and density of their settlement in autumn 1967 and 1968.

\begin{tabular}{|c|c|c|c|c|c|c|c|c|c|c|c|}
\hline \multirow{2}{*}{\multicolumn{5}{|c|}{$\begin{array}{l}\text { Autumn (Oct., 1967) } \\
\text { „Standard Minimum" area, } \\
(5.76 \text { ha) }\end{array}$}} & \multicolumn{6}{|c|}{ Autumn (Oct., 1968) } & \multirow{3}{*}{$\begin{array}{l}\text { barrier } \\
\mathrm{N}_{\mathrm{t}} / \mathrm{ha}\end{array}$} \\
\hline & & & & & \multicolumn{3}{|c|}{$\begin{array}{c}\text { Total area studied } \\
(7.39 \mathrm{ha})\end{array}$} & \multicolumn{3}{|c|}{$\begin{array}{l}\text { Area with a half of } \\
\qquad(5.07 \mathrm{ha})\end{array}$} & \\
\hline $\mathrm{N}$ & $\mathrm{N} / \mathrm{ha}$ & $\mathrm{N}_{\mathrm{t}}$ & $\mathrm{N}_{\mathrm{t}} / \mathrm{ha}$ & $\mathrm{N}$ & $\mathrm{N} / \mathrm{ha}$ & $\mathrm{N}_{\mathrm{t}}$ & $\mathrm{N}_{\mathrm{t}} / \mathrm{ha}$ & $\mathrm{N}$ & $\mathrm{N} / \mathrm{ha}$ & $\mathrm{N}_{\mathrm{t}}$ & \\
\hline \multicolumn{12}{|c|}{ C. glareolus } \\
\hline 62 & 11.2 & 53 & 9.2 & 250 & A. $t a$ & uricus & 29.6 & 146 & 28.6 & 150 & 29.3 \\
\hline 62 & 11.2 & 38 & 6.6 & - & $\bar{A} . a g$ & rarius & - & - & - & - & - \\
\hline- & - & - & - & 57 & $\begin{array}{l}7.7 \\
\text { Tot }\end{array}$ & $\begin{array}{l}55 \\
\mathrm{~N}\end{array}$ & 7.4 & 27 & 5.3 & 34 & 6.7 \\
\hline 124 & 21.5 & 91 & 16.8 & 325 & $\begin{array}{l}44.0^{\circ} \\
\text { Tot: }\end{array}$ & $\begin{array}{l}313 \\
\mathrm{~N}_{\mathrm{t}}\end{array}$ & 42.3 & 209 & 39.2 & 230 & 45.3 \\
\hline 124 & 21.5 & 91 & 16.8 & 393 & 53.2 & 376 & 50.9 & 229 & 45.1 & 259 & 51.1 \\
\hline
\end{tabular}

$\mathrm{N}$ - actual number of rodents caught, $\mathrm{N}_{\mathrm{t}}-$ number of rodents estimated from linear regression.

the calculations given, however, all species have been taken into consideration, thus intentionally allowing a certain error to enter. Table 4 presents the relevant data also with the exclusion of the species referred to. It should be remembered in this connection that Apodemus tauricus also, the density of which was low in autumn 1967, did not exhibit the phenomenon of removal regression.

Density of rodents calculated on the basis of empirical data is more 
than twice greater in the two largest squares (I, II) than in the smallest square. The most even density was found in squares V, VI and VII, measuring from 4.10 to 2.25 ha (Table 2).

The over-estimated densities in the largest squares are undoubtedly due to the edge effect, the character of which was more accurately recorded in the barrier (Fig. 5). It was found that the density of rodents in the barrier zone (belts from 1 to 5) together with its approaches is diversified, maximum density occurring in the middle belt (3), the differences between belts 3 and 2 and between 3 and 4 being statistically significant (Chi-square test). The core of the barrier is formed by lines with closer-set trapping stations (B, C and D). Belts $\mathrm{A}$ and $\mathrm{E}$ have the normal standard spacing of traps and only on account of their proximity

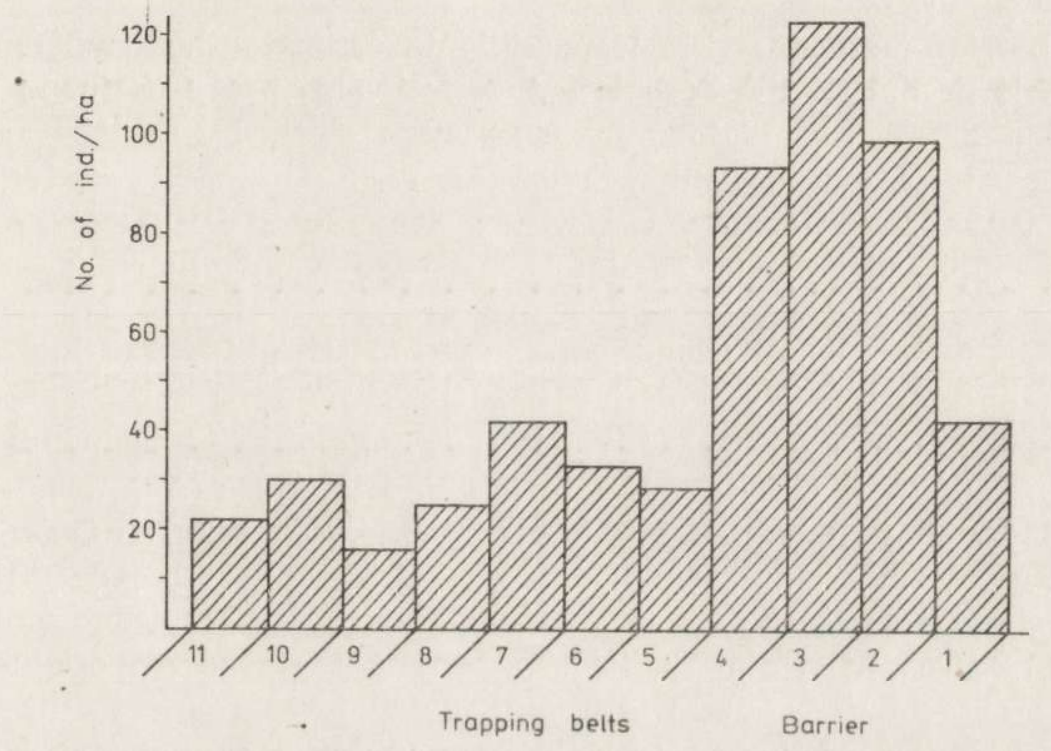

Fig. 5. Density of small rodents in autumn 1968 on modified trapping area converted to area of 1 ha.

to belts $\mathrm{B}$ ad $\mathrm{D}$ acquire a certain significance in the barrier and greatly reinforce it. An assessment of the role of the barrier is therefore based on data from belts B, C and D.

The next problem is that of which data from the various elements of the barrier should be included in calculations, and which eliminated.

It would appear that the line of demarcation runs through the belt with the greatest density of captured rodents (belt 3). This density, in the authors' opinion, was created by the influx of animals both from outside the experimental area and also from its periphery. 
It would seem that in order to make a correct estimate of density of settlement by small rodents it is necessary to take into consideration animals caught within square IV, enlarged by half of belt 3 . This runs through belt $\mathrm{C}$. The area is 5.07 ha in extent and the number of rodents caught in it and estimated density are given in Table 4.

If the whole area of the barrier and number of rodents caught in it were omitted from calculations, then the density of these animals, converted to 1 ha area would be 29.8 individual. Omission from calculations of data relating to the whole barrier area would thus appear to lead to great under-estimation of results. This argues against the proposals put forward by some research workers, that rodents caught in traps situated on the periphery of the study area should be omitted from calculations.

The barrier method makes it possible to estimate the true number of animals producing the edge effect. It may also prove useful in confrontation of results obtained by calculation methods. In the case of trapping carried out in autumn 1968 this estimate appears as follows. The density of all rodents, as already mentioned, calculated on the basis of empirical data, taking into consideration only half the barrier $(5.07 \mathrm{ha})$ was 45.1 individuals per hectare, therefore the number of individuals for the whole trapping area $(7.39 \mathrm{ha})$ should be 330 . Since the total number of rodents caught was 393 (Tables 1,2) the edge effect relates to 63 individuals, which constitutes $16 \%$ of the total number of animals caught. In this case the ratio of areas $(7.39: 7.79)$ was $1: 1.2$. These individuals, with the above density, should inhabit 1.4 ha. This area would form a belt $30 \mathrm{~m}$ wide round the study area. The ratio of experimental area to the whole area inhabited by the captured animals was $1: 1.2$. To put it simply, it may be said that rodents originating from an area of the above width contributed in this case to the edge effect. The entry of these mammals from the surrounding area is not, however, complete and is of a complicated character. As is known, the range of activity in the case of forest rodents is extensive (A d a m c z y k \& Ryszkowski, 1968; Ryszkowski, 1971), and as a result of this and of migration occurring in these animals, part of the individuals caught in the external belts of the barrier should not be considered as immediate neighbours of the experimental area, but as animals entering from places further away.

If, however, it is taken that the density of rodents in square $\mathrm{V}$, calculated after omitting data obtained for the whole barrier, was correct ( 30.5 individuals per hectare), then the number of rodents for the whole study area $(7.39 \mathrm{ha})$ would be 225 . The remainder of the animals caught, i.e., 168 individuals, would be immigrants. The edge effect would 
apply to approximately $40 \%$. These rodents must have originated from an area of 5.5 ha, i.e., forming a belt almost $100 \mathrm{~m}$ in width round the study area. The ratio of the experimental area to the whole of the area from which, on the basis of the calculations given, the captured rodents would have originated would be $1: 1.75$.

The results obtained by $\mathrm{Hanss}$ on (1969) in spruce plantations in the south of Sweden show that the actual range of Clethrionomys glareolus caught on standard areas $(5.8 \mathrm{ha})$ was 8.9 per hectare, Apodemus tauricus - 7.5 per hectare, are of an intermediate value in comparison with these two calculations. For the first of these two species the relative ratio of ranges was $1: 1.54$, and for the second $1: 1.34$. In the light of this author's calculations the edge effect is thus slightly greater. This fact shows that further studies are required if a satisfactory solution of this problem is to be obtained.

It is easy to caleulate in a similar way that 76 individuals emigrated from the more internal parts of the experimental area to the outer part of the barrier. This constitutes $33.4 \%$ of all rodents captured in square IV, increased by half the area of belt 3 . It is therefore clear that this number is even greater than the number of rodents shown for the external part of the barrier. Results recorded for the barrier thus constitute a justifiable plane for arriving at this interpretation.

It must also be recalled that table 4 points to an interesting fact, namely the estimate of densities for different groups of rodents calculated on the basis of empirical data obtained in the autumn of 1968 differs distinctly for the whole of the modified area $(7.39 \mathrm{ha})$ and the area with half the barrier $(5.07 \mathrm{ha})$. The theoretical estimate on the other hand made for the first three trapping days does not reveal any great differences. This would point to the increased degree of passage of these animals through the barrier on subsequent days of the removal cycle carried out.

\section{DISCUSSION}

The results obtained for the area provided with a trap barrier show that the phenomenon of the edge effect is a complicated one, and is caused by the influx of animals both from outside the study area and from its interior. This arises primarily from the fact that the barrier divided the ranges of settled animals both within the experimental area and also on adjacent areas. The barrier traps remove individuals moving from the outside to within the boundaries of the trapping area and also - part of the animals migrating from the innermost parts of this area towards its edge. It would be a mistake to conclude that the edge effect is caused chiefly by influx of rodents from the exterior, with 
simultaneous complete passivity and lack of activity of animals inhabiting part or a large part of the experimental area. The activity of rodents over the area in which bait was laid for several days, may in certain sense be even greatly intensified as a result of the increased concentration of individuals attracted from neighbouring areas, which areas consequently were to some extent deprived of a large number of individuals. Such concentration is of course even more quickly reduced by the eliminating effect of the system of traps. It can be seen from Table 5 that the entry of animals into the external and internal side of the different sides of the barrier may be manifested with different intensity. This phenomenon is undoubtedly also conditioned by differences in the local density of rodents.

Table 5

Percentage of rodents caught on the different side of external and internal belts of the barrier in autumn (October, 1968).

\begin{tabular}{lccc}
\hline \multicolumn{2}{c}{ External } & side of barrier & \multicolumn{2}{c}{ Internal side of barrier } \\
\hline \multicolumn{2}{c}{ Side } & Rodents removed in $\%$ & \multicolumn{2}{c}{ Side } & Rodents removed in $\%$ \\
\hline$a^{1}+b^{1}$ & & & \\
$a^{2}+b^{2}$ & 34.7 & $d^{1}+e^{1}$ & 36.2 \\
$a^{3}+b^{3}$ & 21.4 & $d^{2}+e^{2}$ & 18.7 \\
$a^{4}+b^{4}$ & 27.7 & $d^{3}+e^{3}$ & 22.2 \\
Total & 16.2 & $d^{4}+e^{4}$ & 23.4 \\
\hline
\end{tabular}

A more accurate estimate of the number of rodents inhabiting a defin$€ d$ area and estimate of the edge effect can, in these authors' opinion, be carried out on the basis of data obtained from the area kept free of bait and supplied with a suitable wide barrier formed (e.g. every $5 \mathrm{~m}$ ) cf closely placed traps. The use of bait in itself most certainly contributes to distortion of results, since it must be assumed that as soon as bait is' set out the area automatically becomes differentiated from the surrounding area. The use of bait may cause slowing down of emigration rate and increase in the influx of rodents from surrounding areas, in which the density of these animals consequently decreases. This conclusion can be reached on the basis of results obtained in studies by B o c k \& B a b ińs k a (1967), who showed that more rodents are caught on a baited area than on one free of bait. The experiments made by Buchalczyk \& P ucek (1968) also showed that the number of voles caught in baited snap traps was almost twice greater than the number of animals caught in unbaited traps. This is also confirmed by studies made by Peliká n at al. (1972). As soon as the traps are placed in position and removals begun, the numbers of rodents in the areas where bait is used differ to some extent from the numbers we intend to estimate. 
The authors consider that fluctuations in numbers of rodents in forest ecosystems in different years have not been fully investigated. The results of their own and of other research workers indicate that these fluctuations may be very considerable. The difference found in two successive autumn periods in an ecologically similar area (Ślęża) was more than $100 \%$. In addition it is not known if the data obtained refer to minimum and maximum states of density in numbers of these animals. This fact must be borne in mind since an estimate of the numbers of rodents on the basis of samples from one season does not reflect the true average date and may be burdened with error greater than the error due to the edge effect.

\section{REFERENCES}

1. Adamczyk K. \& Ryszkowski L., 1968: Estimation of the density of a rodent population using stained bait. Acta theriol., 13: 295-311.

2. Aulak W., 1967: Estimation of small mammals density in three forest biotopes. Ekol. pol., 15: 755-778.

3. Bock E. \& Babińska J., 1967: The influence of prebaiting of the catches of rodents. Small Mamml. Newslett., 3: 18-19.

4. Buchalczyk T. \& Pucek Z., 1968: Estimation of the numbers of Misrotus oeconomus using the Standard Minimum Method. Acta theriol., 13: 461-483.

5. Chelkowska H. \& Ryszkowski L., 1967: Causes of higher abundance estimates of small rodents at the edges of sampling areas in forest ecosystems. Ekol. pol., 15: 737-746.

6. Grodziński W., Pucek Z. \& Ryszkowski L., 1976: Estimation of rodent numbers by means of prebaiting and intensive removal. Acta theriol., 11: $294-314$

7. Hanss on L., 1969: Home range, population structure and density estimates at removal catches with edge effect. Acta theriol., 14: 153-160.

8. Pe likán J. 1968: The edge effect of the trapping area in estimates of numbers of small mammals. Zool. listy, 17: 97-108.

9. Pelikán J., Zejda I. \& Holišova V., 1964: On the question of investigating small mammals populations by the quadrate method. Acta theriol. 9: $1-24$.

10. Pelikán J., Zejda J. \& Holišova V., 1972: Influence of prebaiting on the catch of small mammals. Zool. listy, 21: 209-225.

11. Ryszkowski L., 1971: Estimation of small rodent density with the aid of coloured bait. Ann. Zool. Fennici, 8: 8-13.

12. Sz a fer W., (ed.), 1972: Szata roślinna Polski. Państw. Wyd. Nauk., 1+2: $1-614+1-347$. Warszawa.

Accepted, April 15. 1980. 


\section{Stanisław CHUDOBA i Stanisław HUMINSKI \\ OCENA LICZEBNOSCI GRYZONI I EFEKTU KRAWĘDZI NA PODSTAWIE ZMODYFIKOWANEJ METODY "STANDARD MINIMUM"}

1

\section{Streszczenie}

Badania nad liczebnością drobnych gryzoni przeprowadzono w lasach Slęży na wysokości 400-500 m n.p.m. W pierwszym cyklu odlowu (jesienią 1967 r.) zastosowano metodę „standard minimum”, zaś w dwóch następnych (wiosna i jesień 1968 r.) posłużono się zmodyfikowaną powierzchnią łowną powstałą przez zwiększenie areału lownego i utworzenie na jej obwodzie bariery z gęściej ustawionych pulapek. Badania wykazały bardzo wyraźnie zaznaczony efekt krawędzi jesienią 1967 i 1968 roku (Tabela 4). Zjawisko to wystapilo już w pierwszym dniu odłowu i zostało zarejestrowane na utworzonej barierze, dzięki której autorzy uzyskali dane do interpretacji efektu krawędzi. Przekonują one, że efekt ten jest spowodowany zarówno przez imigrację zwierząt $\mathrm{z}$.zewnątrz, jak téz i emigrację ich z obrębu powierzchni lownej. Wskazuje na to charakterystyczny układ zagęszczenia gryzoni na barierze oraz różny stosunek liczby osobników na poszezególnych bokach obwodów zewnętrznych i wewnętrznych bariery.

Przynęcanie jest, zdaniem autorów, zabiegiem wyróżnicowującym korzystnie badaną powierzchnię od terenów sąsiednich i w efekcie prowadzi do zniekształcenia wyników. 